\title{
Urgences
}

\section{Les mémoires artificielles}

\section{Michaël Delisle}

Numéro 15, octobre 1986

Épigraphiques

URI : https://id.erudit.org/iderudit/025281ar

DOI : https://doi.org/10.7202/025281ar

Aller au sommaire du numéro

Éditeur(s)

Urgences

ISSN

0226-9554 (imprimé)

1927-3924 (numérique)

Découvrir la revue

Citer ce document

Delisle, M. (1986). Les mémoires artificielles. Urgences, (15), 12-12.

https://doi.org/10.7202/025281ar

Ce document est protégé par la loi sur le droit d'auteur. L’utilisation des services d'Érudit (y compris la reproduction) est assujettie à sa politique d'utilisation que vous pouvez consulter en ligne.

https://apropos.erudit.org/fr/usagers/politique-dutilisation/
Cet article est diffusé et préservé par Érudit.

Érudit est un consortium interuniversitaire sans but lucratif composé de l'Université de Montréal, l'Université Laval et l'Université du Québec à Montréal. Il a pour mission la promotion et la valorisation de la recherche. https://www.erudit.org/fr/ 


\section{Michaël Delisle \\ LES MÉMOIRES ARTIFICIELLES}

ceci n'est pas une illusion

le paysage s'incline

Claude Beausoleil: d'un texte en préparation

On dit qu'une des particularités de l'esprit baroque consiste en l'effort qu'il met en scène pour intégrer le regardant d'où la popularité des grands formats dans la peinture qui participe de cet univers esthétique. Ces effets de la beauté qui veut rejoindre l'âme du passant on les retrouve dans le génie de Venise. On peut toucher. Le palazzo Venier dei Leoni où loge la collection Peggy Guggenheim - qui n'est qu'un fragment de palais - a quelque chose de baroque dans son esprit. Il s'incline. Se penche sur nous. L'échelle humaine des choses prend tout son sens sur la rue des Assassins. Venelle si étroite que les passants en sens inverse doivent rebrousser chemin. Quand on met les bras en croix on touche sans peine le pan de chaque maison. Et le point de fuite, crevasse bleue, donne le sentinement que le ciel, aussi, est touchable. 